\title{
Expression of a bi-functional and thermostable amylopullulanase in transgenic rice seeds leads to autohydrolysis and altered composition of starch
}

\author{
Chih-Ming Chiang ${ }^{1}$, Feng-Shi Yeh $^{2,3}$, Li-Fen Huang ${ }^{2}$, Tung-Hi Tseng ${ }^{4}$, Mei-Chu \\ Chung $^{4}$, Chang-Sheng Wang ${ }^{4}$, Hu-Shen Lur ${ }^{3}$, Jei-Fu Shaw ${ }^{5}$ and Su-May $\mathrm{Yu}^{2, *}$ \\ ${ }^{I}$ Graduate Institute of Life Sciences, National Defense University, and Institute of Molecular Biology, \\ Academia Sinica, Taipei, Taiwan, R.O.C.; ${ }^{2}$ Institute of Molecular Biology, Academia Sinica, Taipei 115, \\ Taiwan; ${ }^{3}$ Department of Agronomy, National Taiwan University, Taipei 107, Taiwan; ${ }^{4}$ Taiwan Agricultural \\ Research Institute, Wu-Fong, Taichung 413, Taiwa; ${ }^{5}$ Institute of Botany, Academia Sinica, Taipei 115, \\ Taiwan; *Author for correspondence (e-mail: sumay@imb.sinica.edu.tw; phone: +886-2-2788-2695; fax: \\ $+886-2-2788-2695$ or $+886-2-2782-6085)$
}

Received 13 May 2004; accepted in revised form 28 September 2004

Key words: Amylopullulanase, Amylose, High-protein flour, Seed, Starch, Transgenic rice

\begin{abstract}
Overexpression of bacterial-derived starch metabolic enzymes in plant starch storage organs represents a valuable strategy for improving starch quality, bioprocessing and nutritional value. Transgenic rice seeds producing a thermostable and bifunctional starch hydrolase, amylopullulanase (APU) from Thermoanaerobacter ethanolicus 39E, were generated. Starch in these seeds could be hydrolyzed with optimal temperatures between 85 and $95{ }^{\circ} \mathrm{C}$, which resulted in complete conversion of starch into soluble sugars and production of protein-enriched flour within a few hours. By expressing various levels of APU, rice seeds containing reduced amounts of amylose, which is an important factor affecting starch quality, were obtained without a significant impact on grain yield. Elevation in granule-bound pullulanase activity correlates with the reduction of amylose in developing APU-containing rice seeds. APU was found to be localized within amyloplasts and in cell walls, which could be the result of overexpression of APU with a signal peptide. This study establishes novel approaches to alter starch properties, accelerate bioprocessing of starch and production of protein-enriched flour from rice seeds, and could significantly impact the industrial and food uses of cereals.
\end{abstract}

\section{Introduction}

Rice seeds contain abundant starch and high quality proteins and are commonly used in food and beverage industries. Separation of proteins and starch allows for the production of proteinenriched rice flour and starch hydrolysates used in different commercial products. An enzymatic process has been developed to simultaneously produce maltose-enriched syrup and proteinenriched rice flour from milled rice seeds (Shaw and Sheu 1992). In this process, the rice flour is first liquified with thermostable microbial $\alpha$-amylase at a high temperature, and the heat-coagulated proteins are then easily separated from the soluble starch hydrolysate and recovered as protein-enriched flour. The starch hydrolysate is further treated with a microbial $\beta$-amylase and a 
debranching enzyme (isoamylase or pullulanase) to produce maltose-enriched syrup. The maltoseenriched syrup can be used for numerous food processes and alcoholic beverage production. The protein-enriched rice flour has high nutritional value and is useful for the production of baby and health food (Hansen et al. 1981; Morita and Kiriyama 1993).

APU from T. ethanolicus 39E, which harbors both $\alpha$-amylase and pullulanase activities, is capable of hydrolyzing both $\alpha-1,4$ and $\alpha-1,6$ bonds of polysaccharides and is heat stable with a catalytic optimum at $90{ }^{\circ} \mathrm{C}$ (Mathupala et al. 1993; Lin and Leu 2002). The use of transgenic rice seeds containing this thermostable and bi-functional APU would theoretically facilitate liquefaction and saccharification of starch simultaneously at high temperature without the need to add exogenous $\alpha$-amylase and pullulanase. Such an application would be desirable for health food production, simplifying the sugar and protein production process, improving the efficiency of starch bioprocessing, and significantly reducing production cost.

Starch is composed of two different glucan chains, amylose and amylopectin. Amylose is a linear polymer of glucosyl residues linked via $\alpha-1,4$ glucosidic linkages, whereas amylopectin exists as a branched $\alpha-1,4 ; \alpha-1,6$ D-glucan polymer. Synthesis of amylose is catalysed by granule-bound starch synthase (GBSS) through the addition of glucose residues to the linear $\alpha$-1,4-glucosyl chain, whereas the starch branching enzyme and soluble starch synthase introduce $\alpha-1,6$ linkages on linear chains to form amylopectin (Preiss 1991). The relative amount of amylose and amylopectin affects the unique physical and chemical properties of starch, which confers specific functionality and could be of biotechnological importance (Slattery et al. 2000). Modification of levels and properties of the starch biosynthetic enzymes has been accomplished by the identification of starch biosynthetic mutants and transgene technology. However, these approaches have generally led to significantly lower yield (Visser and Jacobsen 1993; Slattery et al. 2000).

In the present study, APU was highly expressed in both mature and germinated transgenic rice seeds under the control of rice glutelin and $\alpha$-amylase gene promoters. We demonstrated that sugar syrup and protein-enriched flour were produced simultaneously from complete autohydrolysis of starch in flour derived from transgenic seeds upon heating at $85^{\circ} \mathrm{C}$ for only a few hours. Surprisingly, we also observed that amylose content in transgenic rice seeds was reduced, without affecting starch content, plant growth and grain yield. We found that APU expressed with a signal peptide was localized within amyloplasts where starch biosynthesis and pullulanse activity were affected.

\section{Materials and methods}

\section{Plants and bacteria}

The rice variety Oryza sativa L. cv Tainung 67 was used throughout this work. T. ethanolicus 39E (ATCC53033) was obtained from the American Type Culture Collection. Bacterial and rice genomic DNA were purified for using as templates for PCR. In all quantitative analyses, 20 dehulled seeds from each of three individual plants of an independent transgenic line were used. Each data point represents the average of three replicates.

\section{Plasmid construction}

Promoters of the rice glutelin gene (GluB-1) and $\alpha$ amylase gene $(\alpha A m y)$ having high activities in developing (Wu et al. 1998) and germinated (Itoh et al. 1995; Yu et al. 1996) rice seeds, respectively, were used for directing the expression of APU in transgenic rice seeds. The 1351-bp rice GluB- 1 (Wu et al. 1998) promoter plus a 75-bp nucleotide sequence encoding a putative 25 -amino acid signal peptide (SP) of GluB-1 (Gp) and the GluB-1 promoter plus a 183-bp nucleotide sequence encoding a peptide containing the putative SP and 36 extra amino acids (Gpp) were PCR-amplified. The putative SP cleavage site was predicted based on a statistical method (von Heijne 1985). For ease of manipulation, a 2865-bp DNA fragment of the Apu gene, encoding amino acids 75 to 1029 of the mature APU of T. ethanolicus (Mathupala et al. 1993; Lin and Leu 2002), was used for rice transformation. The truncated $A p u$ was PCR-amplified and fused upstream of nopaline synthase gene (Nos), $\alpha A m y 3$ or $\alpha A m y 8$ terminators (Sheu et al. 1996; Chan and Yu 1998). The GluB-1 promoter 
plus SP was fused upstream of $A p u$ to make translational fusions, which were then inserted into the binary vector pSMY1H (Ho et al. 2000) to generate pGpApu and pGppApu. The 1.7- and $0.5-\mathrm{kb}$ promoters plus SP sequences of $\alpha A m y 3$ and $\alpha A m y 8$ (Chan et al. 1994; Lu et al. 1998), respectively, were fused upstream of $A p u$ to make translation fusions, which were then inserted into pSMY1H to generate pA3Apu and pA8Apu. These plasmids were used for rice transformation.

To generate the $\alpha A m y 3$ promoter-GFP chimeric gene, a $1.7-\mathrm{kb}$ DNA fragment containing the promoter region of $\alpha A m y 3$ with or without the SP sequence of $\alpha A m y 3$ was PCR-amplified using plasmid p3G-132II (Lu et al. 1998) as the DNA template. The two DNA fragments were cloned into pBluescript SKII + (Stratagene) to generate pBS-Amy3P ( $\alpha$ Amy3 promoter only) and pBSAmy3PSP ( $\alpha A m y 3$ promoter plus SP sequence). The sGFP(S65T) cDNA encoding a modified GFP (Chiu et al. 1996) was inserted downstream of the $\alpha A m y 3$ promoter to make a transcriptional fusion or inserted downstream of the $\alpha A m y 3$ promoter and SP sequences to make a translational fusion, which were then inserted into the binary vector pSMY1H to generate pA3-GFP and pA3-SPGFP.

\section{Rice transformation}

Plasmids were introduced into Agrobacterium tumefaciens strain EHA101 (Hood et al. 1986) that was used for rice transformation as described (ToKi 1997). The nomenclature for the transgenic lines was designated first by showing the promoter used for construct, followed by one digit representing $\mathrm{T} 1$ generation of a transgenic line, and then followed by a digit representing $\mathrm{T} 2$ subline of the T1 transgenic line. For example, transgenic line A3-7 is the $\mathrm{T} 1$ generation of a line carrying $\alpha A m y 3$ promoter, $\mathrm{A} 3-7-2$ is the $\mathrm{T} 2$ generation of line A3-7.

\section{Expression of APU in E. coli and preparation of polyclonal antibodies}

The truncated $A p u$ was subcloned into the vector pET20b(+) (Novagen, Madison, Wisconsin) for expression of APU in E. coli strain BL21 (DE3).
The expressed APU was used for raising polyclonal antibodies.

\section{Protein gel blot analysis}

Total medium proteins were collected by centrifugation at $18,000 \times g$ at $4{ }^{\circ} \mathrm{C}$ for $15 \mathrm{~min}$ to remove cell debris. Protein concentration was determined with the protein assay reagent (Pierce) based on the Bradford method with BSA as a standard. Protein gel blot analysis was performed using the rabbit anti-APU polyclonal antibodies diluted at 1:2000.

Determination of APU level using an enzyme-linked immunosorbent assay (ELISA)

Total soluble proteins from rice suspension cells or seeds were prepared as described (Chen et al. 2002). APU level was determined with ELISA as described (Ausubel et al. 1992) using the E. coli expressed APU as a standard. The rabbit antiAPU antibodies were used at a dilution of $1: 3000$.

\section{Autohydrolysis of starch}

Rice seeds were ground and prepared as a $1 \%$ slurry in Good's buffer containing $50 \mathrm{mM}$ each of $N, N$-bis-(2-hydroxyethyl)-glycine, 3-[cyclohexylamino]-1 -propanesulfonic acid, sodium acetate, and [1,3-bis[tri-(hydroxy-methyl) methylaminopropane], $\mathrm{pH}$ 5.0. The slurry was heated at $85^{\circ} \mathrm{C}$ for various lengths of time, centrifuged at $15,000 \times g$ for $5 \mathrm{~min}$, and the supernatant and precipitate were separately collected. Starch and soluble sugar content were determined as described (Chen et al. 1994).

\section{Determination of amylose content}

Starch granules were isolated from rice seeds as described (Zeeman et al. 1998). Amylose content in starch granules was determined by a colorimetric method (Juliano 1971; Nishi et al. 2001) using a Technicon Autoanalyzer II (Bran \& Luebbe, Norderstedt, Germany). Serial dilutions 
of purified amylose from potato (Sigma, St. Louis, Missouri) were used as standards.

\section{Statistical analysis}

The data were analyzed with a computer-based Statistical Analysis System (SAS) version 8.2 (SAS Institute Inc., Cary, NC, USA). The relationship between amylose content and APU level was determined by linear regression and expressed by the Pearson's correlation coefficient $(r)$. A significant level of $p<0.05$ was considered significant. The comparison of starch, protein and oil contents and seed weight between APU and NT seeds was determined by the Dunnett's test at the significant level of $p<0.05$.

\section{Analysis of seed protein content}

Crude protein content in rice seeds was determined by a modified Kjeldahl method described in Approved Methods of the American Association of Cereal Chemists (AACC Method 46-12) (Chemists 1995). Rice flour $(0.5 \mathrm{~g})$ was mixed with catalyst $(0.4 \mathrm{~g})\left(\mathrm{CuSO}_{4}: \mathrm{K}_{2} \mathrm{SO}_{4}=1: 10\right)$ in a digestion flask and $4.0 \mathrm{ml} \mathrm{H}_{2} \mathrm{SO}_{4}$ was added. The mixture was incubated at room temperature overnight. The sample was heated in a Digestion System (Teactor, Sweden) at $420{ }^{\circ} \mathrm{C}$ for $2 \mathrm{~h}$ (the dense white fumes became clear in the bulb of the flask) and then cooled down to room temperature. Distilled water $(20 \mathrm{ml})$ was added, and the sample was placed in the Kjeltec Auto 1030 Analyzer (Teactor, Sweden). The distillate was titrated with $0.05 \mathrm{M}$ $\mathrm{NaOH}$ solution to neutrality using the methyl red indicator. Amount of crude protein was calculated as: $\%$ protein $=14.01 \times \mathrm{M} \times f \times(\mathrm{ml}$ titrant $-\mathrm{ml}$ blank) $/ \mathrm{g}$ samples $\times 100$, where $\mathrm{M}=$ normality of $\mathrm{NaOH}(0.05 \mathrm{M}) ; f=5.95$ (standard Kjeldhl factor for rice).

\section{Analysis of seed oil content}

Oil content in rice seeds was determined by a described method (Williams 1984) with slight modifications. Rice flour $(2 \mathrm{~g})$ was placed in a filter cup and then in a preheated $\left(95^{\circ} \mathrm{C}\right)$ aluminum cup containing anhydrous ether. The aluminum cup was transferred to the oil extraction apparatus Soxtex System HT2 (Tecator, Sweden) that had been set at $95^{\circ} \mathrm{C}$. After $2 \mathrm{~h}$, the filter cup containing flour was removed and the aluminum cup was placed in a $95^{\circ} \mathrm{C}$ oven until constant weight was obtained. Amount of oil was calculated as: \% oil $=$ weight of oil (corrected with blank $) \times 100 /$ weight of sample.

\section{Assay of pullulanase activity in developing seeds}

Starch granules were prepared at $0-4{ }^{\circ} \mathrm{C}$ as described (Jiang et al. 2003). Ten dehulled grains with embryo and pericarp removed were handhomogenized with a glass homogenizer in $2 \mathrm{ml}$ of $50 \mathrm{mM}$ HEPES- $\mathrm{NaOH}$ (pH7.4) buffer containing $4 \mathrm{mM} \mathrm{MgCl}_{2}, 2 \mathrm{mM}$ EDTA, $50 \mathrm{mM}$ 2-mercaptoethanol and $12.5 \%(\mathrm{v} / \mathrm{v})$ glycerol. The homogenate was centrifuged at $10,000 \times g$ for $10 \mathrm{~min}$, and the pellet was washed $(2 \mathrm{ml} \times 2)$ with the same buffer. The pellet (starch granules) was collected and resuspended in the same buffer $(2 \mathrm{ml})$ for activity assays of the following granule-bound starch metabolizing enzymes.

Pullulanase activity was determined by a published method (Mathupala et al. 1993) with slight modifications. The assay was conducted at $40{ }^{\circ} \mathrm{C}$ for $30 \mathrm{~min}$ in a reaction mixture $(200 \mu \mathrm{l})$ containing $1.25 \%$ pullulan $(\mathrm{w} / \mathrm{v}), 50 \mathrm{mM}$ acetic acid$\mathrm{NaOH}$ (pH 6.0), $5 \mathrm{mM} \mathrm{CaCl}_{2}$, and enzyme preparation $(40 \mu \mathrm{l})$. The reaction was stopped by adding $0.8 \mathrm{ml}$ of dinitro salicylate solution and heated in boiling water for $15 \mathrm{~min}$. The sample was cooled on ice and $\mathrm{A}_{640}$ was determined. $\mathrm{A}$ standard curve using known amounts of glucose was established. One unit of pullulanase activity was defined as the amount of enzyme which produces $1 \mu \mathrm{mol}$ of reducing sugar (with glucose as standard) per min per endosperm.

\section{EM immunocytochemistry (EMI)}

Tissues or cells were fixed with $3 \%$ paraformaldehyde and $0.25 \%$ glutaraldehyde and then prepared for EMI as previously described (Chen et al. 1994). The APU antibodies were diluted at 1:200. The anti-mouse ADH monoclonal antibody (Abcam, Cambridge, UK) was diluted at 1:50. Colloidal gold (18 nm diameter)-conjugated goat 
anti-rabbit IgG and goat anti-mouse IgG (Jackson, Pennsylvania) were used as the secondary antibodies.

\section{Assays of enzyme activity in mature seeds}

Enzymes were prepared at $0-4{ }^{\circ} \mathrm{C}$. Twenty dehulled seeds, with embryo and pericarp removed, were hand-homogenized with a glass homogenizer in $2 \mathrm{ml}$ of CCLR buffer containing $100 \mathrm{mM} \mathrm{KH} \mathrm{PO}_{4}$ (pH 7.8), $1 \mathrm{mM}$ EDTA, $10 \%$ glycerol, $1 \%$ triton X-100, $7 \mathrm{mM}$ 2-mercaptoethanol. After centrifugation at $10,000 \times g$ for $10 \mathrm{~min}$, the supernatant (whole seed extract) was collected for enzyme activity assay. The pellet was collected and starch granules were further purified as described (Zeeman et al. 1998). The purified starch granules were hand-homogenized with a glass homogenizer in $2 \mathrm{ml}$ of CCLR buffer and used for enzyme activity assay. Total protein content in whole seed extract or starch granule fraction was determined with a Coomassie Protein Assay Kit (Pierce Biotechnology).

APU activity was determined with the same method as used for determination of pullulanase activity in developing seeds, except that prior to assay of APU activity, the protein preparations from whole seed extract and starch granule fraction were heated at $90{ }^{\circ} \mathrm{C}$ for 30 min to inactivate endogenous pullulanase, and the assay for APU activity was conducted at $85^{\circ} \mathrm{C}$. Phytase (Hong et al. 2004), luciferase ( $\mathrm{Lu}$ et al. 1998; Chen et al. 2002) and ADH (Xie and Wu 1989) activities were determined as described.

\section{Confocal microscopy}

Transformed rice calli were cultured in Murashige and Skoog medium containing $50 \mu \mathrm{g} / \mathrm{ml}$ hygromycin until the green fluorescence could be detected under a dissecting fluorescence microscope (Olympus). Transformed calli expressing GFP were selected and transferred to sucrose-free medium for 2 days. Protoplasts were then isolated from the rice calli as previously described ( $\mathrm{Lu}$ et al. 1998). The protoplasts expressing GFP were imaged with a Zeiss confocal microscope using a 488$\mathrm{nm}$ laser line for excitation and a 515-560 nm-long pass filter for emission.

\section{Results}

APU accumulation in culture media of transformed rice suspension cells is sugar-regulated

Plasmids carrying the 2865-bp Apu fused downstream of the $\alpha A m y$ or GluB promoter plus the $\alpha$ Amy or GluB signal peptide (SP) sequence (Figure 1a) were individually delivered into the rice genome. The putative transformed rice calli were selected with hygromycin and identity of the transformants was confirmed with genomic DNA gel blot analysis (data not shown). Transformed rice calli were cultured in liquid MS medium to generate suspension cell cultures. Accumulation of APU RNA in the transformed calli was detected with RNA gel blot analysis (data not shown). The culture media were collected from four transformed lines and subjected to protein gel blot analysis for estimation of APU accumulation. APU was detectable in the culture medium of cell line A3-7 under sucrose starvation (Figure 1b, lane 5 ) but was undetectable when sucrose was provided (Figure 1b, lane 4). By contrast, APU was detectable in the culture media of cell lines Gpp-1, Gpp-2 and $\mathrm{Gp}-9$ when sucrose was provided (Figure 1b, lanes 8-10). APU was undetectable in the culture medium of non-transformed (NT) cells. This result confirmed the specificity of the anti-APU antibodies, which were then used in the ELISA for APU quantification in subsequent experiments.

APU was present in all culture media of transformed suspension cells but not in the media of NT cells (Figure 1c). The levels of APU varied among cell lines, probably due to a position and/or gene copy effect on transgene expression. The presence of APU in the culture media indicated that the putative SP sequence of GluB-1 was capable of directing translocation of APU through the secretory pathway. The $\alpha A m y 3$ and $\alpha A m y 8$ promoters directed higher levels of APU expression in the absence than in the presence of sucrose, which was expected as the activity of $\alpha A m y 3$ and $\alpha$ Amy 8 promoters is up-regulated by sucrose starvation (Chan et al. 1994; Lu et al. 1998). Interestingly, the GluB-1 promoter directed a higher level of APU expression in rice suspension cells in the presence than in the absence of sucrose. The sucrose up regulation of $G l u B-1$ promoter was more apparent in the $G l u B(1)$ construct than in the $G l u B(2)$ construct. 
(a) pGpApu

Nos 3'
GluB-1 promoter sp

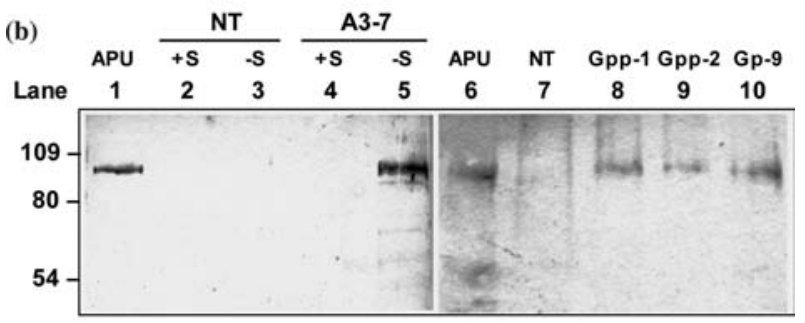

(c) $214 \quad a^{+ \text {sucrose }}$

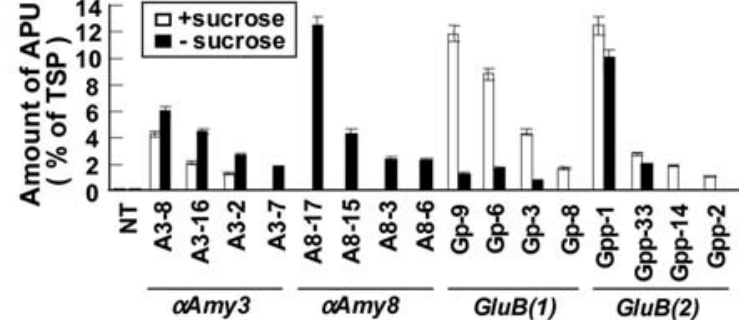

(d)

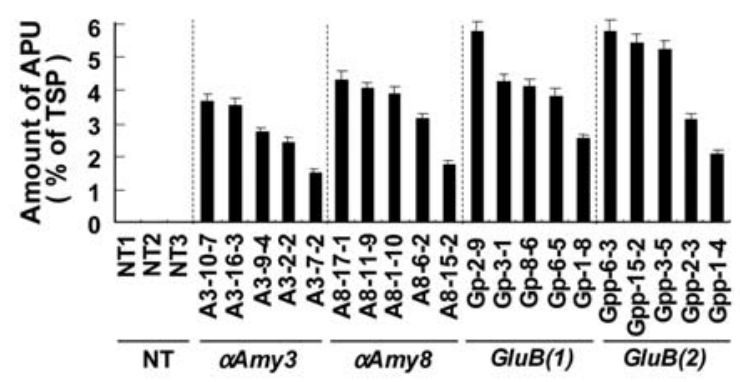

(e)

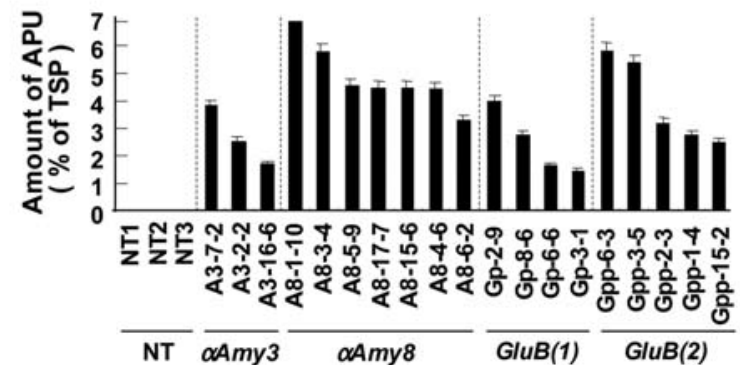


APU accumulates in germinated and mature transgenic rice seeds

Transgenic plants were regenerated from the transformed calli. More than 80 independent transgenic lines were obtained for each construct. The transgenic rice lines were self-fertilized for two generations and T2 transgenic seeds were obtained for further analysis. Transgenic seeds were identified by germination in water containing $50 \mu \mathrm{g} / \mathrm{ml}$ hygromycine for 7 days. APU levels in mature transgenic rice seeds were determined. APU expressed under the control of the GluB-1, $\alpha A m y 3$ and $\alpha A m y 8$ promoters accumulated in mature seeds, with no APU detected in NT seeds (Figure 1d). Although the levels of APU varied among transgenic lines, the GluB-1 promoter generally conferred a higher level of APU expression in mature transgenic rice seeds than the $\alpha A m y 3$ and $\alpha A m y 8$ promoters.

Transgenic rice seeds were also germinated for 5 days and the APU levels determined. APU expressed under the control of GluB-1, $\alpha A m y 3$ and $\alpha A m y 8$ promoters accumulated in germinated seeds, with no APU detected in NT seeds (Figure 1e). The $\alpha A m y 8$ promoter generally conferred a higher level of APU expression in germinated transgenic rice seeds than the $\alpha A m y 3$ and GluB- 1 promoters.

\section{Sugar syrup and protein-enriched rice flour are produced simultaneously from complete hydrolysis of starch at $85-95^{\circ} \mathrm{C}$}

To determine whether starch in transgenic rice seeds expressing APU (APU rice seeds) could be autohydrolyzed at high temperatures, whole grains of transgenic line Gpp-6-3 were ground to flour, suspended in buffer, and incubated at various temperatures for $1 \mathrm{~h}$. The starch content reduced (Figure 2a, left panel), while the soluble sugar content increased (Figure 2a, right panel), in both transgenic seeds and NTs upon heating. However, the amounts of starch hydrolyzed and sugars produced were much higher in APU rice seeds than in NTs. The optimal temperatures for starch hydrolysis by APU ranged between 85 and $95^{\circ} \mathrm{C}$. APU lost its activity at $100^{\circ} \mathrm{C}$.

To determine to what extent the starch in APU rice seeds could be converted to sugars upon heating, the rates of starch hydrolysis and production of soluble sugars in seeds of four transgenic lines, expressing various levels of APU, were measured at $85^{\circ} \mathrm{C}$. Starch in transgenic seeds was hydrolyzed rapidly and the concentration of soluble sugars increased significantly with incubation time (Figure 2b, upper and middle panels, respectively). The total weight of sugars produced in each transgenic line was equal to the total weight of starch $(67-82 \%$ of seed weight) being hydrolyzed, indicating complete hydrolysis of starch upon heating. There is a correlation between APU activities and the starch-to-sugars conversion rates. Lines Gpp-6-3, Gp-3-1, Gpp-1-4, and A8-15-2 contained 58, 42, 29 and $17 \mu \mathrm{g}$ APU per $\mathrm{mg}$ total soluble proteins, respectively, and the times required for starch in these lines to be completely converted to sugars were approximately 4, 8, 12 and $16 \mathrm{~h}$, respectively. The results suggest that the more APU present in seeds, the faster the rate of starch hydrolysis to sugars. In NTs, only

Figure 1. Expression of APU in transformed rice suspension cells and transgenic rice seeds. (a) Expression cassettes for rice transformation. pGpApu contains the $G l u B-1$ promoter-signal peptide (sp)-Apu cDNA-Nos $3^{\prime}$ chimeric construct. pGppApu contains the GluB-1 promoter-sp-extra 108 bp (x)-Apu cDNA-Nos 3' chimeric construct. pA3Apu contains the $\alpha A m y 3$ promoter-sp-Apu cDNA$\alpha A m y 33^{\prime}$ chimeric construct. pA8Apu contains the $\alpha A m y 8$ promoter-sp-Apu cDNA- $\alpha A m y 83^{\prime}$ chimeric construct. (b) Specificity of anti-APU antibodies. APU collected from culture media of cell lines A3-7 Gpp-1, Gpp-2 and Gp-9 was subjected to protein gel blot analysis using anti-APU antibodies. Lanes $2-5$, cells cultured in the presence $(+\mathrm{S})$ or absence $(-\mathrm{S})$ of sucrose. Lanes $7-10$, cells cultured in the presence of sucrose. Samples in lanes 1-5 and 6-10 were analyzed in two separate gel blots. E. coli-expressed APU was used as a positive control. Amounts of total proteins loaded in each lane: lanes 1 and 6, E. coli APU, $1 \mu \mathrm{g}$; lanes 2-5, 100 $\mu \mathrm{g}$; lanes 7 and 8,10 $\mu \mathrm{g}$; lane 9, $100 \mu \mathrm{g}$; lane 10,10 $\mu \mathrm{g}$. (c) APU accumulation in culture media of transformed rice suspension cells. Transformed $\mathrm{T}_{0}$ suspension cells were cultured in medium with $3 \%$ sucrose (open bar) or without sucrose (filled bar) for 2 days. (d) APU accumulates in mature transgenic seeds. (e) APU accumulates in transgenic seeds germinated for 5 days. Total soluble protein (TSP) was collected from the culture media or extracted from seeds and the amounts of APU were determined with ELISA. Twenty dehulled seeds from each of three individual plants of each independent transgenic line were used in the analysis. The data represent averages of three repeats of the analysis with standard deviation. $\alpha A m y 3$ : $\alpha A m y 3$ promoter; $\alpha A m y 8$ : $\alpha A m y 8$ promoter; GluB(1): G luB-1 promoter $+\mathrm{SP}$; GluB (2): GluB-1 promoter + SP + extra 108 bp. 
(a)

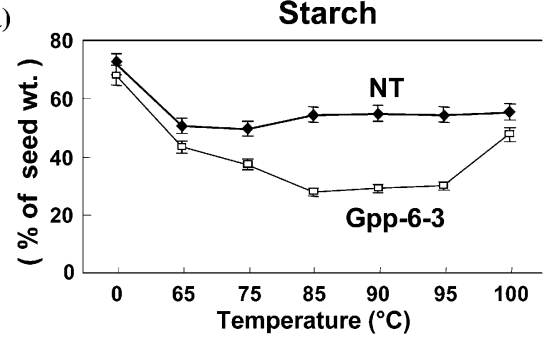

Sugars

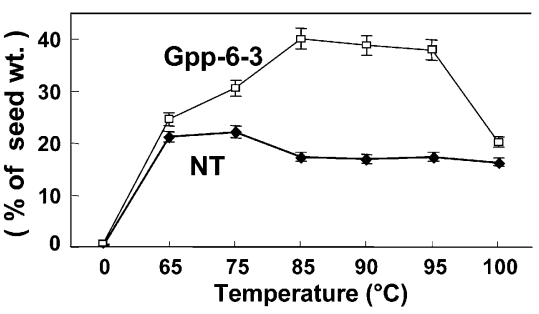

(b)

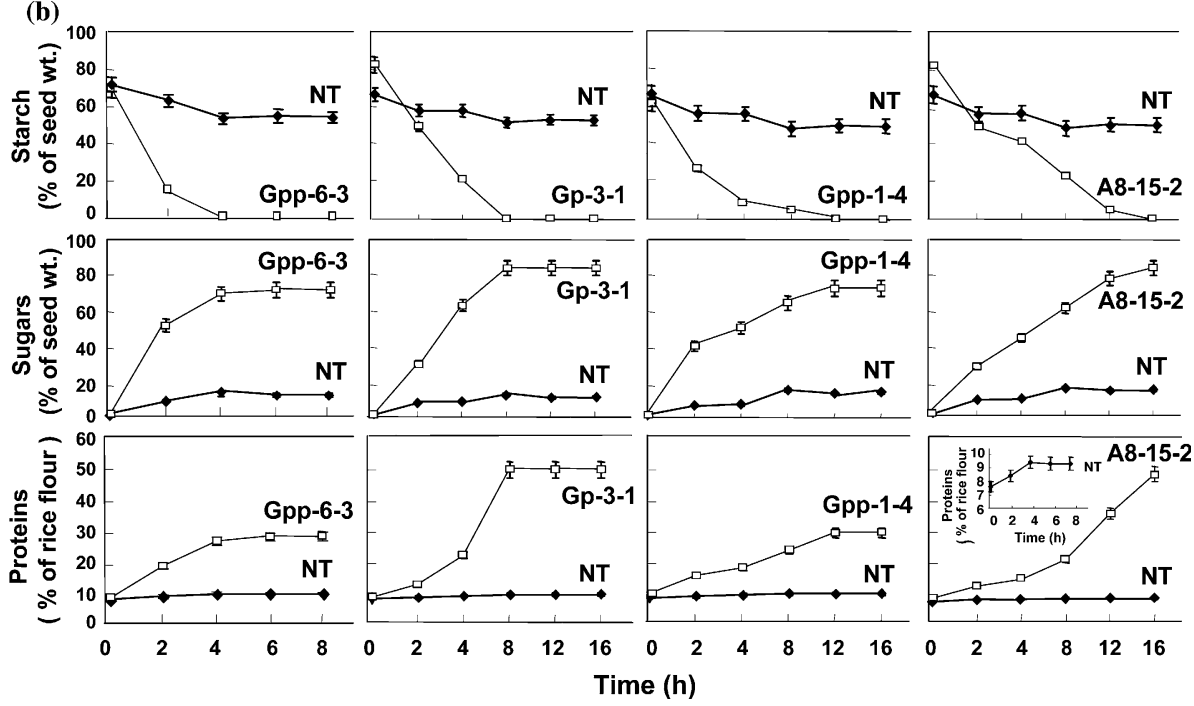

Figure 2. Sugar syrup and protein-enriched rice flour are produced simultaneously by complete hydrolysis of starch at $85-95{ }^{\circ} \mathrm{C}$ within a few hours. (a) Seed slurries of line Gpp-6-3 and NTs were heated at various temperatures for $1 \mathrm{~h}$, and starch (left panel) and sugar (right panel) contents determined. (b) Seed slurry was heated at $85{ }^{\circ} \mathrm{C}$ for various lengths of time and starch, sugar and protein contents were determined. The inset at the lower right panel shows that the yield of protein in the rice flour of NT seeds increased approximately $2 \%$ after starch hydrolysis. Twenty dehulled seeds from each of three individual plants of each independent transgenic line were used for analysis of each parameter. The data represent averages of three repeats of the analysis with standard deviation.

$10-15 \%$ of starch was hydrolyzed to sugars up to $16 \mathrm{hr}$.

To determine whether protein-enriched rice flour was produced during starch hydrolysis, the hydrolysates were centrifuged and the protein content in the precipitated paste was determined. Protein content in the precipitated flour of transformants increased with incubation time and reached peak levels at 4, 8, 12 and $16 \mathrm{~h}$ (Figure 2b, lower panel), respectively, paralleling the kinetics of starch-to-sugars conversion. The yields of proteins in the precipitated flour ranged between 30 and $50 \%$ (dry base) for transgenic lines and 10\% for NTs. These results demonstrated that sugar syrup and protein-enriched rice flour could be produced simultaneously from APU-driven starch hydrolysis.
Ectopic expression of APU reduces amylose content in transgenic rice seeds

During characterization of starch in APU rice seeds, we found that levels of amylose content appeared to be reduced in many transgenic lines. Consequently, among 350 independent transgenic lines, 81 lines grown in the same season and field were randomly selected and analyzed for seed amylose content. Among these transgenic lines, 6 lines $(8 \%)$ had similar and 75 lines $(92 \%)$ had reduced amounts of amylose than the NT seeds. The results of 57 represented lines are shown in Figure 3a. The amylose content in wild type seeds was approximately $18 \%$ of total seed starch content, while that of the majority of APU seeds ranged from 9 to $18 \%$ of total starch content. To rule out the 


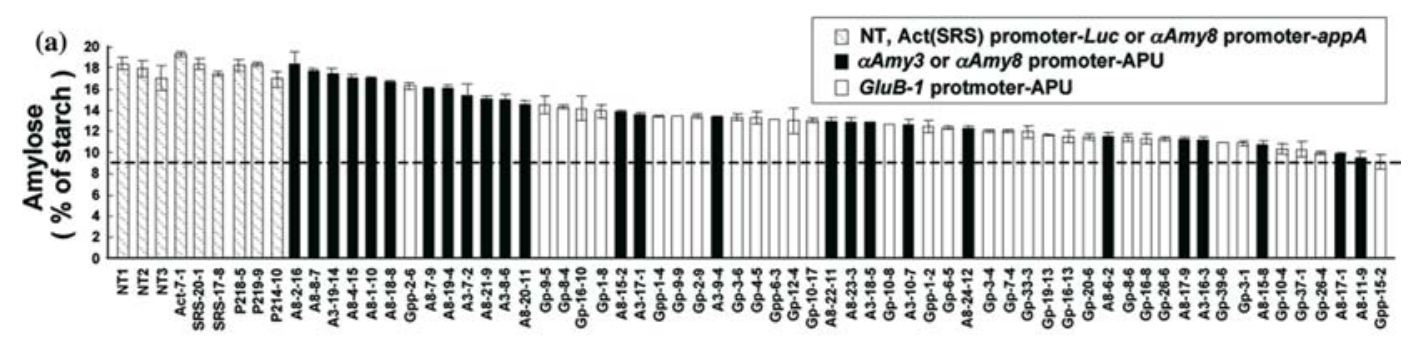

(b) (1)

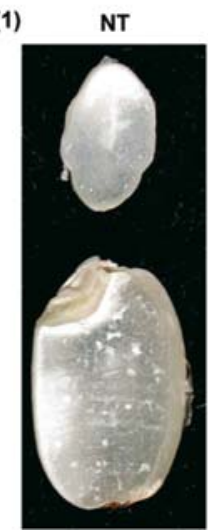

(2)

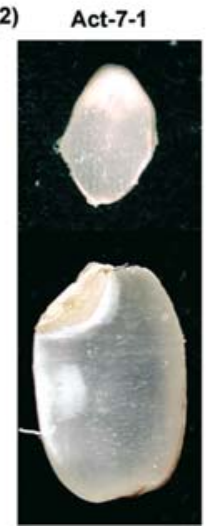

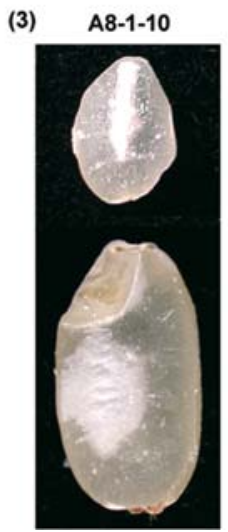
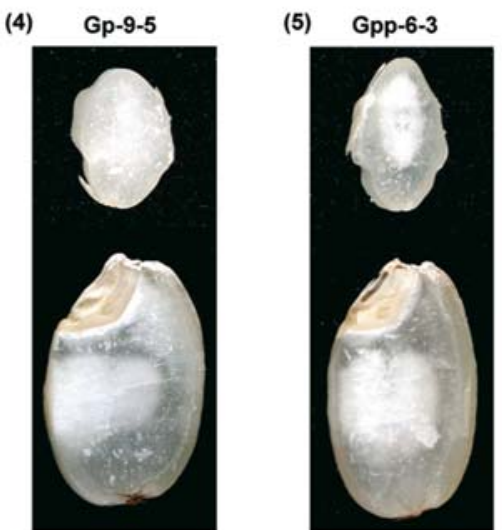

Figure 3. Ectopic expression of APU reduces amylose content in transgenic rice seeds. (a) Amylose content in T2 seeds of 57 transgenic lines expressing $A p u$ under the control of $\alpha A m y 3$ or $\alpha A m y 8$ promoter (filled bars) and GluB-1 promoter (open bars) were determined. Amylose contents in NTs and transgenic lines expressing luciferase or phytase (stippled bars) were also determined. Horizontal dash line indicates the lowest level of amylose content in transgenic lines. Twenty dehulled seeds from each of three individual plants of each independent transgenic line were used in the analysis. The data represent averages of three replicates of the analysis with standard deviation. (b) Chalky phenotype of APU seeds. Seeds of NT (panel 1), line expressing luciferase (panel 2), and lines expressing APU (panels 3-5) were longitudinally cut (left) and cross-cut (right).

possibility that alteration in amylose levels was due to somaclonal variation from the transformation and tissue culture procedures, the amylose content in control transgenic rice seeds was also determined. These control seeds express a firefly luciferase gene ( $\mathrm{Luc}$ ) under the control of an Act1 (SRS) promoter (Chen et al. 2002) or a bacterial phytase gene (appA) under the control of $\alpha A m y 8$ promoter and SP sequence (Hong et al. 2004). The results show that the seed amylose levels in these control transgenic plants were similar to that of NT seeds (Figure 3a). Our observations indicate that the amylose content was preferentially reduced in APU rice seeds and the reduction was up to $50 \%$ of the level found in NTs.

Examination of APU seed morphology reveals that the wild type seeds (Figure 3b, panel 1) and transgenic seeds expressing luciferase (as a control) (Figure 3b, panel 2) generally are more translucent and contain a narrow opaque white (chalky) region at the ventral side of the endo- sperms. However, most of the APU seeds contain a much larger chalky region extending from the ventral side toward the center of the endosperm (Figure 3b, panels 3-5), with opaque white appearance, more like glutinous rice seeds that contain low amylose content. The chalky phenotype of APU seeds was observed up to eight generations.

\section{Accumulation of APU correlates with reduction of amylose content in transgenic rice seeds}

To determine whether the alteration in amylose content resulted from overexpression of APU, transgenic seeds with differing amylose contents were randomly selected for determination of APU levels. NT seeds and transgenic seeds expressing luciferase and phytase did not contain APU but had high amylose content (Figure 4a). In contrast, the APU seeds had higher APU levels but lower amylose content than control 

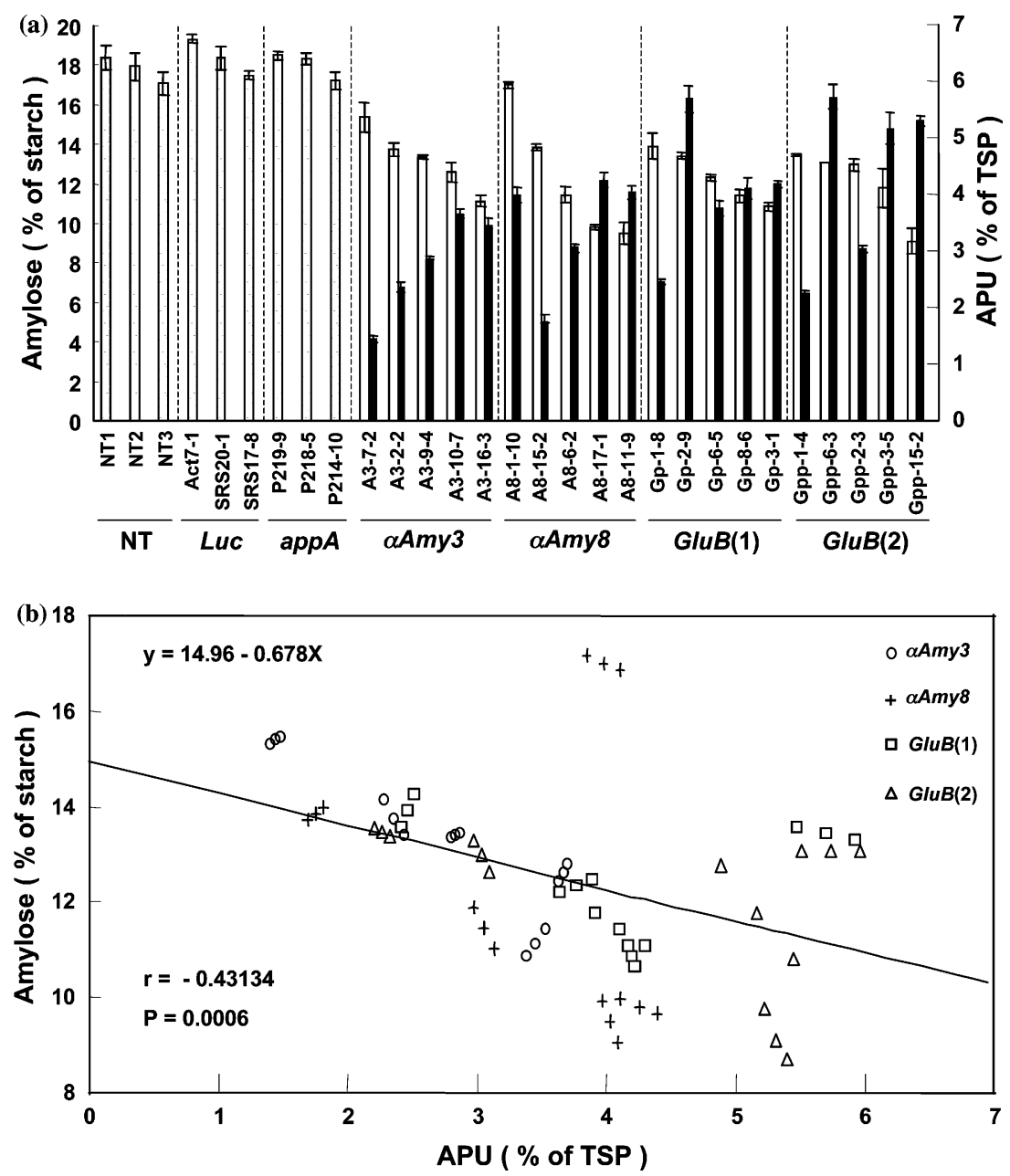

Figure 4. Accumulation of APU correlates with reduction of amylose content in transgenic rice seeds. (A) Amylose content (open bars) and APU level (filled bars) in seeds of 20 transgenic lines expressing Apu under the control of $\alpha A m y 3, \alpha A m y 8$ or GluB-1 promoter were determined. Amylose contents in seeds of NT and transgenic lines expressing luciferase or phytase (stippled bars) were also determined. Twenty dehulled seeds from each of three individual plants of each independent transgenic line were used for analysis of APU level or amylose content. Luc: lines expressing luciferase. appA: lines expressing phytase. TSP: total soluble proteins. (b) Scattergram showing inverse correlation between APU levels and amylose content in transgenic seeds. Each data point represents average value of 20 seeds. Total of 60 values $(n=3$ replicates $\times 5$ lines $\times 4$ constructs $=60)$ were plotted and analyzed statistically.

seeds. Statistical analyses were performed to determine whether there was a correlation between APU level and amylose content in transgenic seeds. In APU seeds, values for amylose content spanned a range of $8 \%$ points $(9-17 \%)$ of starch, and values for APU level spanned a range of $4.2 \%$ points $(1.5-5.7 \%)$ of total soluble protein (TSP) (Figure 4a). Plots of APU levels against amylose content are shown in a scattergram (Figure 4b), in which the Pearson correlation coefficient $(r)$ relating the two variables is $-0.43134(p=0.0006, n=60)$ and the regression line fits equation: amylose content $=14.96-0.678 \times$ APU content, indicating a negative and linear covariance. The statistical analyses suggest an inverse correlation between APU level and amylose content in APU seeds.

To determine whether the total starch, protein and oil content and seed weight of APU seeds was changed in a reciprocal fashion, these parameters were also analyzed. Three independent 
Table 1. Comparison of starch, protein, and oil content and seed weight between APU and control seeds.

\begin{tabular}{|c|c|c|c|c|}
\hline & Lines & No. of sample & Mean $\pm \mathrm{SD}$ & Significance \\
\hline \multirow[t]{7}{*}{ Starch content ( $\%$ of seed wt.) } & NT & 15 & $69.82 \pm 2.77$ & - \\
\hline & Act-SRS-Luc & 9 & $69.96 \pm 2.29$ & 0.144 \\
\hline & аAmy8-арр $A$ & 9 & $69.23 \pm 2.59$ & -0.587 \\
\hline & aAmy3-Apu & 15 & $68.53 \pm 3.23$ & -1.287 \\
\hline & $\alpha A m y 8-A p u$ & 15 & $71.69 \pm 5.89$ & 1.875 \\
\hline & $G l u B(1)-A p u$ & 15 & $73.43 \pm 5.29$ & 3.608 \\
\hline & GluB (2)-Apu & 15 & $69.53 \pm 6.44$ & -0.292 \\
\hline \multirow[t]{7}{*}{ Protein content ( $\%$ of seed wt.) } & NT & 15 & $7.76 \pm 0.23$ & - \\
\hline & Act-SRS-Luc & 9 & $7.40 \pm 0.29$ & -0.357 \\
\hline & аAmy8-арр $A$ & 9 & $7.95 \pm 0.44$ & 0.19 \\
\hline & aAmy3-Apu & 15 & $8.97 \pm 0.60$ & $1.206^{*}$ \\
\hline & $\alpha A m y 8-A p u$ & 15 & $9.55 \pm 0.79$ & $1.791^{*}$ \\
\hline & GluB (1)-Apu & 15 & $8.19 \pm 0.60$ & 0.43 \\
\hline & GluB (2)-Apu & 15 & $8.82 \pm 0.76$ & $1.062^{*}$ \\
\hline \multirow[t]{7}{*}{ Oil content ( $\%$ of seed wt.) } & NT & 15 & $2.31 \pm 0.08$ & - \\
\hline & Act-SRS-Luc & 9 & $2.31 \pm 0.06$ & -0.005 \\
\hline & аAmy8-арр $A$ & 9 & $2.29 \pm 0.13$ & -0.126 \\
\hline & aAmy3-Аpu & 15 & $2.19 \pm 0.18$ & -0.007 \\
\hline & аAmу8-Apu & 15 & $2.19 \pm 0.23$ & -0.018 \\
\hline & GluB (1)-Apu & 15 & $2.30 \pm 0.23$ & -0.125 \\
\hline & GluB (2)-Apu & 15 & $2.33 \pm 0.16$ & 0.017 \\
\hline \multirow[t]{7}{*}{ Seed weight (g/20 seeds/line) } & NT & 15 & $0.423 \pm 0.007$ & - \\
\hline & $A c t-S R S-L u c$ & 9 & $0.427 \pm 0.004$ & 0.004 \\
\hline & $\alpha A m y 8$-app $A$ & 9 & $0.421 \pm 0.007$ & -0.002 \\
\hline & аAmy3-Apu & 15 & $0.422 \pm 0.007$ & -0.001 \\
\hline & $\alpha A m y 8-A p u$ & 15 & $0.452 \pm 0.008$ & $0.029^{*}$ \\
\hline & GluB (1)-Apu & 15 & $0.437 \pm 0.016$ & 0.014 \\
\hline & GluB (2)-Apu & 15 & $0.439 \pm 0.014$ & $0.016^{*}$ \\
\hline
\end{tabular}

The same 20 transgenic lines as those analyzed in Figure 4, expressing Apu under the control of $\alpha A m y 3, \alpha A m y 8$ or GluB-1 promoter, and NT and transgenic lines expressing luciferase or phytase were analyzed. Twenty dehulled seeds from each of three individual plants of each independent transgenic line (sample number $=3 \times 3$ or $3 \times 5$ lines per construct) were used for statistic analysis of each parameter. The data represent averages of three repeats of the analysis with standard deviation (SD).

*Dunnett's test. The mean difference between transformants and NT is significant at the 0.05 level.

lines transformed with $\operatorname{Act}(S R S)$-Luc construct or $\alpha$ Amy8-SP-appA construct were randomly selected for comparison. As shown in Table 1, no difference in these parameters was observed between lines expressing luciferase or phytase and NTs. No difference in starch and oil content was observed between APU and NT seeds. Protein content in lines expressing APU under the control of $\alpha A m y 3, \alpha A m y 8$ and $G l u B(2)$ promoters, and seed weights in lines expressing APU under the control of $\alpha A m y 8, G l u B(1)$, and $G l u B(2)$, were significantly higher than NT seeds. Although generally protein content and seed weight appear to be higher in transgenic seeds expressing APU than NT seeds, no correlation between these parameters with APU levels could be observed. Studies on transgenic seeds with higher protein content and weight would be continued in the future.
Pullulanase activity is increased in developing APU rice seeds

To investigate whether expression of APU in transgenic rice seeds is developmentally regulated, APU activity in developing seeds of two transgenic lines was determined. Accumulation of APU was not detected in NT seeds, but detected in transgenic seeds and increased with time after pollination (Figure 5a). Accumulation of APU was significantly elevated 20-25 days after pollination.

To further investigate whether APU accumulation might contribute to total pullulanase activity in developing rice seeds, the granule-bound pullulanase activity in developing rice endosperm was determined. The total granule-bound pullulanase activity was found to be higher in transgenic seeds than in NT seeds across the entire grainfilling period (Figure $5 b$ ). 

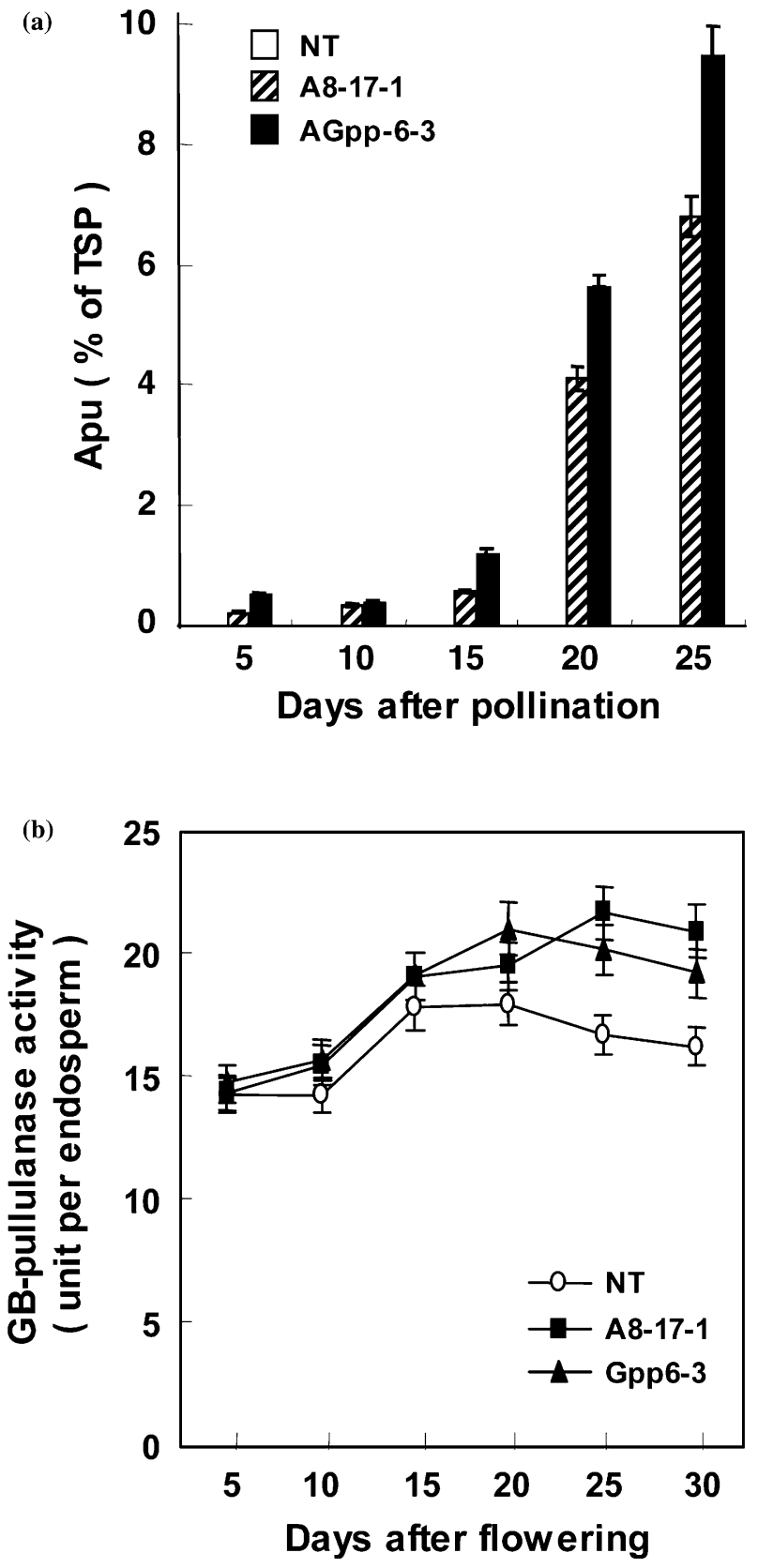

Figure 5. Pullulanase activity is increased in developing APU rice seeds. Rice seeds were collected periodically after pollination and APU accumulation and pullulanase activity were determined. (a) Accumulation of APU in developing transgenic rice seeds. Total soluble proteins (TSP) were extracted from seeds and the amounts of APU were determined with ELISA. (b) Total activity of granulebound pullulanase in developing transgenic rice seeds. Twenty dehulled seeds from each of three individual plants of each independent transgenic line were used for each analysis. The data represent averages of three repeats of the analysis with standard deviation.

APU is localized in cell walls and amyloplasts

APU was expressed with an SP derived from $\alpha$ Amy3, $\alpha$ Amy8 or GluB. The subcellular localiza- tion of APU in transformed rice cells was examined using electron microscopic immunocytochemistry (EMI). Surprisingly, in addtion to being secreted (Figure 1c), APU was localized not only in cell walls 

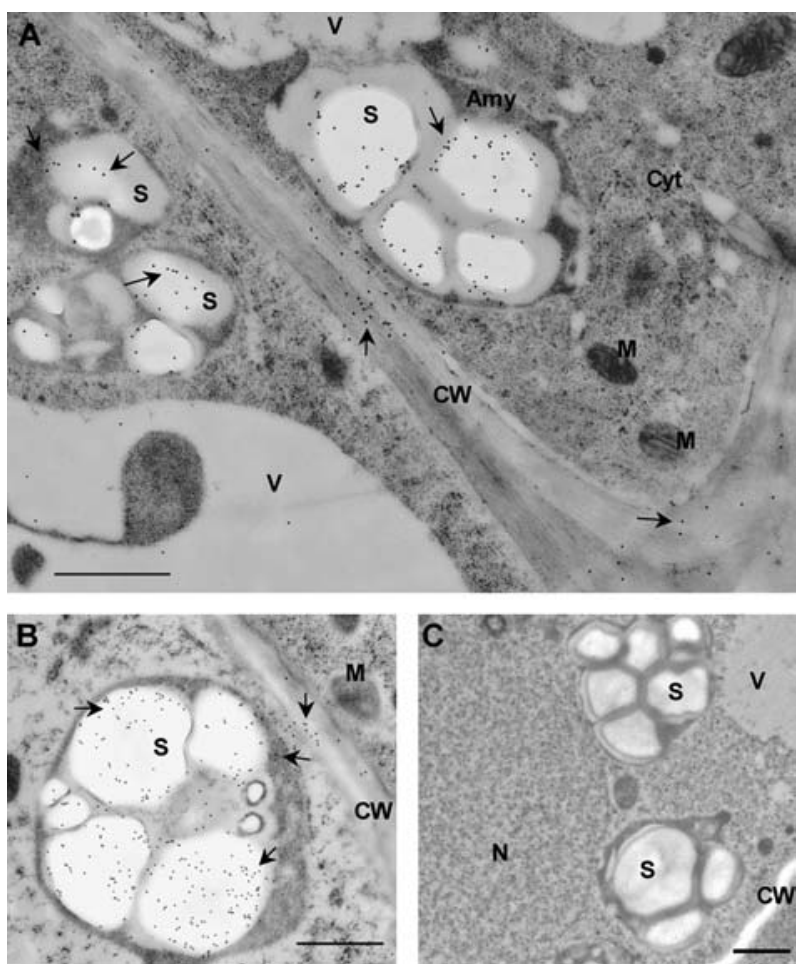

Figure 6. APU is localized in cell walls and amyloplasts/starch grains. Immunocytochemical localization of APU in cultured rice suspension cells using anti-APU antibodies. APU was labeled in cell walls and starch grains of transformed line Gpp6-3 (a) and line A8-17-1 (b). No APU was labeled in NT after reaction with the antibodies (c). Abbreviations: Amy, amyloplast; CW, cell wall; M, mitochondria; N, nucleus; S, starch granules; V, vacuole. Arrow heads indicate positions of APU. Bar scale $=1 \mu \mathrm{m}$.

but also in starch grains and stroma of amyloplasts of transformed suspension cells (Figure 6a and b). APU was not detected in the counterparts of NTs (Figure 6c) or cells expressing phytase or luciferase (data not shown). Similar APU localization was observed in developing APU rice seeds. To rule out the possibility that APU antibodies might bind to starch grains non-specifically, a mouse antibody that recognizes the rice alcohol dehydrogenase $(\mathrm{ADH})$ was also used in the EMI study as a control. $\mathrm{ADH}$ is a cytosolic marker enzyme and present exclusively in the extra-plastidial region (Tetlow et al. 2003). With the ADH antibody, ADH was labeled in the cytoplasm but not in the cell wall, and only background level gold particles were detected in starch granules (data not shown), indicating that localization of gold-labeled APU in starch grains was not a result of non-specific labeling.

Biochemical approaches were also employed to demonstrate that APU was localized in amyloplasts. Activities of APU, phytase, luciferase and
$\mathrm{ADH}$ in whole seed extracts and in the purified starch grain fraction were determined. Phytase was expressed with an SP derived from $\alpha$ Amy8 (Hong et al. 2004). APU and phytase activities were detected in both seed extracts and in the starch grain fraction of transformants expressing APU and phytase, respectively, but not in other seeds (Figure 7a and b). The amounts of APU and phytase associated with starch grains were approximately 20 and $30 \%$, respectively, of that present in whole seed extracts. Luciferase was expressed without SP, and its activity was detected only in seed extracts of transformants expressing luciferase (Figure 7c). ADH activity was detected only in seed extracts of both transformants and NTs (Figure 7d). The absence of both luciferase and ADH suggests that the purified starch grain fraction was free of contamination with cytosolic enzymes.

To confirm that the SP could indeed direct translocation of a cargo protein into amyloplasts, 
(a)

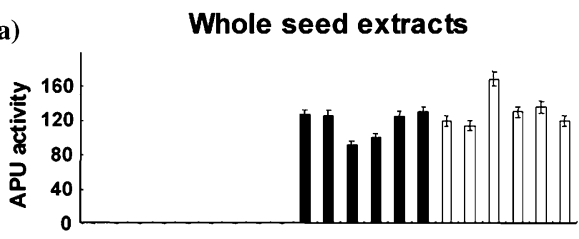

(b) 0.25

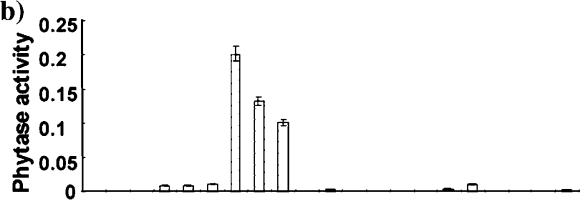

(c)
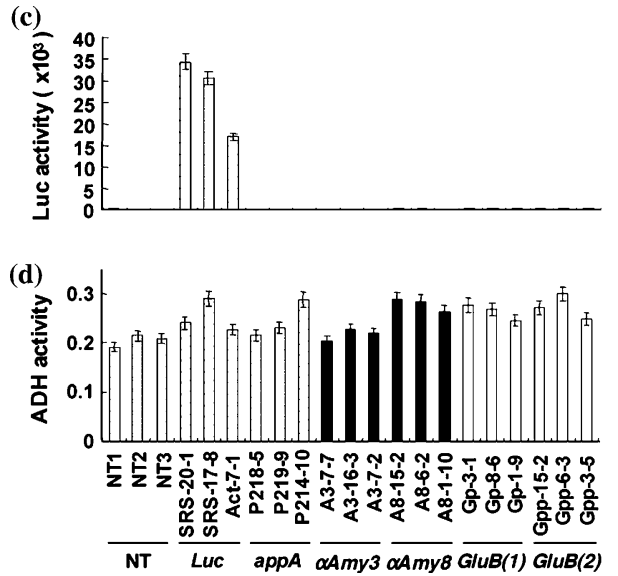
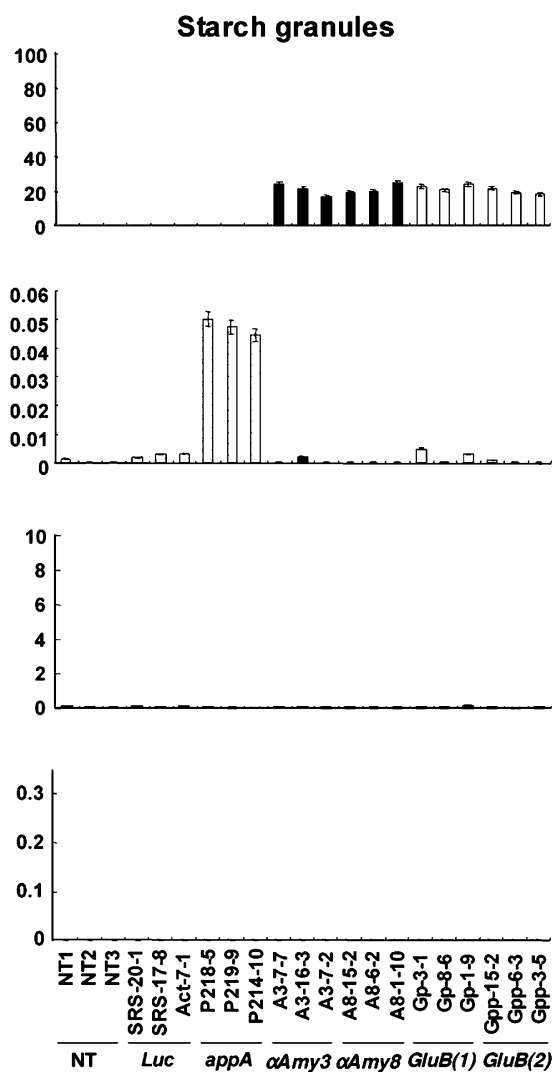

Figure 7. APU is associated with starch granules inside amyloplasts. Activity assays of (a) APU, (b) phytase, (c) luciferase (Luc) and (d) ADH in whole seed extracts (left panel) and purified starch fractions (right panel) of non-transformants (NT) and transgenic lines expressing Luc, phytase $(a p p A)$ and APU. Definition of activity: APU, $\mu \mathrm{M}$ reducing sugar $/ \mathrm{min} \mu \mathrm{g}$ total soluble proteins (TSP); phytase, units/min·mg TSP; luciferase, light units/ $\mu \mathrm{g}$ TSP; ADH, OD/min·mg TSP.

chimeric genes (Figure 8a and e) encoding GFP with or without the $\alpha$ Amy 3 SP under the control of the rice $\alpha A m y 3$ promoter were constructed and introduced into the rice genome. Rice protoplasts were then isolated from the transformed calli and the sub-cellular localization of GFP was analyzed using confocal microscopy. GFP without the SP was found throughout the cytoplasm as well as in the nucleus but not in vacuoles, nucleolus of organelles that appear to be amyloplasts containing starch grains (Figure 8b-d). As the non-fluorescent amyloplasts might overlap with the fluorescent cytoplasm, the image of amyloplasts appeared as irregular punctuated organelles (Figure $8 \mathrm{c}$ ). By contrast, GFP with the $\alpha$ Amy $3 \mathrm{SP}$ was targeted mainly to amyloplasts (Figure $8 \mathrm{f}-\mathrm{h}$ ). This study further demonstrates that SP is capable of directing a cargo protein to plastids.

\section{Discussion}

In the present study, transgenic rice lines have been generated by expressing a bi-functional thermostable APU from T. ethanolicus 39E. The approach of using the thermostable APU as a process aid is novel, as it significantly reduces the incubation time in processing, leading to complete autohydrolysis of starch into sugar syrup within only a few hours, as compared with conventional enzymatic methods (Shaw and Sheu 1992). The complete hydrolysis of starch is important for maximal recovery of sugar syrup and proteins as well as for avoiding chocking of filters during processing. APU rice seeds could be used directly or as a source of APU, in the substitution of microbial amylolytic enzymes, to convert starch into liquefied starch hydrolysate, which can be 

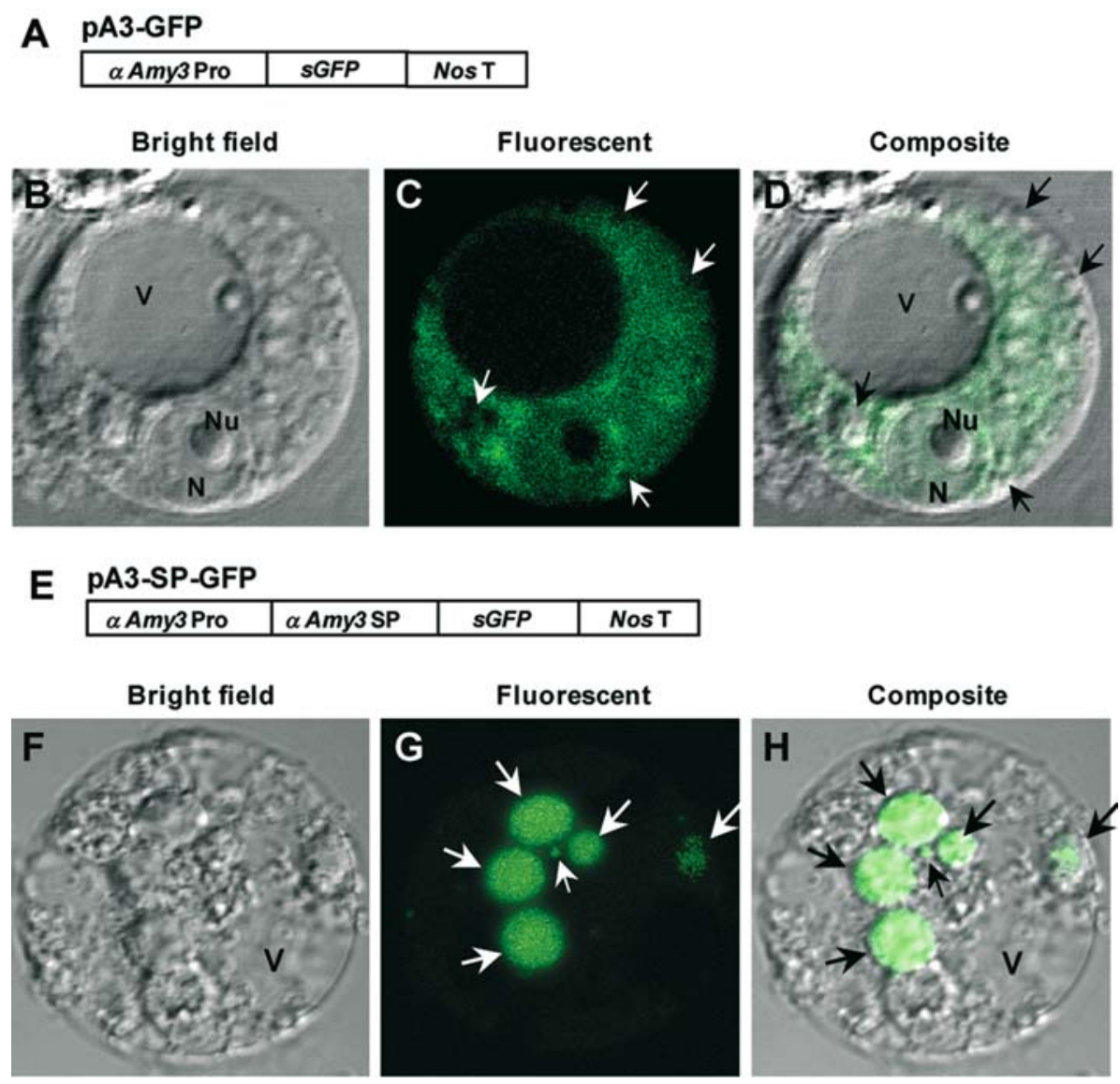

Figure 8. SP-dependent targeting of GFP to plastids. Protoplasts were isolated from transformed rice calli expressing GFP and examined under the confocal microscope. (a) Construct (pA3-GFP) used for rice transformation. (b-d) GFP without an SP was detected in cytoplasm and nucleus. (e) Construct (pA3-SP-GFP) used for rice transformation. (f-h) GFP with the $\alpha$ Amy3 SP was detected in amyloplasts. (b and f) Bright field images. (c and g) Fluorescent field images. (d and h) Composite images of fluorescence (green pseudo color) and transmission. Abbreviations: V, vacuole; N, nucleus; Nu, nucleolus. Arrowheads indicate positions of amyloplasts.

further used for the industrial production of sweetners or fermentation products.

Rice is the major cereal crop in Asian countries and is a staple food for almost $50 \%$ of the world population. The nutritional quality of rice proteins is considered to be better than that of wheat proteins (Murata et al. 1973), and is comparable with meat and milk proteins if the rice proteins are supplemented with two limiting amino acids, lysine and threonine (Chang et al. 1986). However, the protein content of rice, which is usually $6-10 \%$, is too low to be adequate for young children, for whom a protein content of $20-25 \%$ is recommended (Hansen et al. 1981). Although genetic manipulations have been attempted to increase the protein content of rice to $10-15 \%$, this is still not adequate and some essential amino acids decrease in the mutant cultivars (Hansen et al. 1981). Enzymatic hydrolysis of starch offers an alternative method for the production of protein-enriched flour with improved nutrition (Shaw and Sheu 1992; Morita and Kiriyama 1993). However, the use of exogenous microbial thermostable enzymes increases the processing cost. The yield of proteins from the four randomly selected transgenic lines ranged between 30 and $50 \%$ of rice flour after starch hydrolysis. Our study shows that the processing of APU rice seeds for simultaneous production of protein-enriched flour and sugar syrup is simple, efficient and inexpensive. It may also provide people in developing countries with 
Table 2. Yield and phenotype of $\mathrm{T} 5$ transgenic rice expressing APU.

\begin{tabular}{lllll}
\hline & NT & A8-17-7 & Gpp-6-3 & Gpp-3-5 \\
\hline Seed weight (g/plant) & $101.8 \pm 3.8$ & $128.7 \pm 6.88$ & $107.1 \pm 12.4$ & $102.7 \pm 4.7$ \\
Plant height (cm) & $109.9 \pm 6.5$ & ND & $104.5 \pm 4.6$ & ND \\
Tiller number & $15.0 \pm 4.5$ & ND & $16.4 \pm 4.6$ & ND \\
\hline
\end{tabular}

Each value is the mean $\pm \mathrm{SD}(n=15)$; ND: not-determined.

an easily accessible and important source of nutritious proteins in their diets.

Although $\alpha$-amylase promoter activity is regarded as specifically inducible during germination, $\alpha$-amylase activity has been detected in developing maize kernels (Thevenot et al. 1992). The $\alpha A m y 3$ and $\alpha A m y 8$ promoters used in the present study may contain DNA sequences capable of conferring expression in both developing and germinating seeds, or it is possible that their activities are not tightly controlled during seed development. In our experiments, although APU was expressed under the control of the GluB-1 promoter, no APU mRNA was detected in mature and germinating seeds. This suggests that APU detected in germinated seeds could have accumulated during seed development rather than having been synthesized during germination. Nevertheless, $\alpha A m y 3, \alpha A m y 8$ and GluB-1 promoters are competent for conferring accumulation of APU in transgenic mature or germinated rice seeds. The GluB-1 promoter activity is stronger in transgenic developing rice seeds, whereas the $\alpha A m y 8$ promoter activity is stronger in transgenic germinating rice seeds. Consequently, an appropriate promoter could be chosen depending on whether mature or germinated seeds are intended to be used for production of APU.

Another unique feature of APU rice seeds is that they have reduced amylose contents, which could be useful for certain applications. Amylose content affects rice quality such as palatability and industrial uses. It is a key determinant of the eating and cooking quality of rice; high amylose levels are usually associated with dry, fluffy and non-sticky rice grains (Juliano 1985). A transgenic approach, by antisense inhibition of GBSS (Waxy gene), has been employed for reduction of rice amylose content (Terada et al. 2000; Liu et al. 2003); however, a reduction in grain weight (yield) with this approach occurred (Liu et al. 2003). The approach for generating transgenic rice with varying degrees of reduction in amylose content, by overexpressing an APU which favors amylopectin biosynthesis, is novel and effective for improvement of rice quality without an impact on grain yield. In general, the higher APU levels, the lower the amylose content detected. Transgenic line A8-1-10, which has high APU level but no significant reduction of amylose content, is an exception (Figure 4a). It is interesting to note that overexpression of APU led to reduction of seed amylose content; however, total starch content was unchanged (Table 1). This suggests that the reduction in amylose biosynthesis is probably compensated by an increase in amylopectin biosynthesis in APU seeds.

Several transgenic lines expressing APU have been propagated over eight generations and over a period of six years, with the Apu gene stably inherited in progenies. Phenotype of transgenic plants and seed formation was normal and yield of some lines was normal up to T5 generation (Table 2), except the seeds were characterized with a chalky phenotype. The chalky phenotype appears to be due to seeds containing less amount of amylose, as starch from chalky rice seeds contains less amylose (more amylopectin) and more short branch-chain amylopectin (less long-chain amylopectin) compared with the translucent seeds (Patindol and Wang 2003). Transgenic rice seeds expressing an antisense Waxy gene, leading to reduced amylose level, also show chalky phenotype (Terada et al. 2000; Liu et al. 2003).

The total granule-bound pullulanase activity in developing rice seeds was determined at $40{ }^{\circ} \mathrm{C}$, which is closer to the plant growth temperature in fields but is not an optimal temperature for APU activity. The higher total granule-bound pullulanase activity in APU rice seeds than in NT seeds suggests that APU accumulated in developing transgenic rice seeds could be active at plant growth temperature. If this is the case, it may account for the observed effects of APU expression on seed amylose content. Despite the general 
view that isoamylase/pullulanase are debranching enzymes, studies with the rice (sugary-1) and maize (zpul) mutants suggest that they are actually needed for amylopectin biosynthesis in endosperm (Kubo et al. 1999; Dinges et al. 2003). In this study, the higher granule-bound pullulanase activity detected in developing APU rice seeds may therefore favor amylopectin biosynthesis in APU seeds. The other possibility that overexpression of APU indirectly affects starch synthesis by affecting other enzymes required for amylose biosynthesis could not be ruled out.

It is noted that the difference in granule-bound pullulanase activities between developing seeds of transgenic lines and NT (Figure 5b) is not as prominent as the difference in APU activities detected in mature seeds (Figure 7a). The reason could be activity of pullulanase in developing seeds was analyzed at $40{ }^{\circ} \mathrm{C}$ but in mature seeds was analyzed at the optimal temperature, $85^{\circ} \mathrm{C}$.

If APU is involved in starch biosynthesis in plastids, it would be expected to be present in the plastids. Two observations indicate that APU could somehow be carried into amyloplasts in addition to being secreted extracellularly. First, the anti-APU antibodies only labeled the starch grains or amyloplast stroma of cells expressing APU but not those of NTs or cells expressing phytase or luciferase. Second, only APU or phytase expressed with SP could be detected in starch grain fractions of transgenic seeds. The exact mechanism of plastid localization of APU is unclear. It is possible that a fraction of SP-containing APU ends up in plastids due to the overexpression of this protein. This notion is supported by the observation that GFP fused with an $\alpha$ Amy3 SP was targeted to amyloplasts. Earlier observation has shown that a significant amount of assembled antibodies could be found in chloroplasts, in addition to being detected in the endoplasmic reticulum, when mature light and heavy chains of a monoclonal antibody fused with a barley $\alpha$-amylase SP were overexpressed in transgenic tobacco (During et al. 1990). Recently, the B subunit of an E. coli heat-labile enterotoxin (LT-B) was found to be associated with starch grains in amyloplasts when this protein, carrying its native SP or fused with a maize $\gamma$-zein SP, was overexpressed in transgenic maize endosperm (Chikwamba et al. 2003). By gain- and loss-offunction analyses, we have also demonstrated that the $\alpha$ Amy 3 and $\alpha$ Amy 8 SPs are necessary and sufficient for directing dual localizations of cargo proteins to plastids and cell walls in leaf messophyll and cultured suspension cells of transgenic tobacco and rice (Chen et al. 2004).

In conclusion, the present study has generated novel APU-containing rice seeds with three unique features: (1) complete starch autohydrolysis within a few hours incubation at $85-95^{\circ} \mathrm{C}$; (2) can be processed efficiently and cost effectively for simultaneous production of protein-enriched flour and sugar syrup for human consumption and broad industrial uses; and (3) reduction in amylose contents without having a significant impact on grain yield. This study also shows that APU expressed with a SP could be targeted to amyloplasts where this enzyme affects activity of granulebound starch metabolizing enzymes and starch biosynthesis. Our study demonstrates the technical feasibility of improving nutritional and commercial values of rice through a biotechnological approach. Similar approaches could also be applied to other cereals or tuber crops, e.g., maize, potato and cassava, which might offer even lower production cost than rice.

\section{Acknowledgement}

Jei-Fu Shaw's and Su-May Yu's labs contributed equally to this work. We thank Dr Tuan-hua David Ho for critical review of the manuscript, Drs Pen-Wen Chen, Chwan-Yang Hong and Cheng-Yi Lii and Ms Ai-Ling Hour and Lin-Chih $\mathrm{Yu}$ for technical assistance. This work was supported by grants from Academia Sinica and the National Science Council (NSC88-2317-B-001-017 and NSC89-2317-B-001-010) of the Republic of China.

\section{References}

Ausubel F.M., Brent R., Kingston R.E., Moore D.D., Seidman J.G., Smith J.A. and Struhl K. 1992. In: A Compendium of Methods from Current Protocols in Molecular Biology. John Wiley \& Sons, New York pp. 11-19.

Chan M.T., Chao Y.C. and Yu S.M. 1994. Novel gene expression system for plant cells based on induction of alphaamylase promoter by carbohydrate starvation. J. Biol. Chem. 269: 17635-17641.

Chan M.T. and Yu S.M. 1998. The 3' untranslated region of a rice alpha-amylase gene mediates sugar- dependent abundance of mRNA. Plant J. 15: 685-695. 
Chang K.C., Lee C.C. and Brown G. 1986. Production and nutritional evaluation of high-protein rice flour. J. Food. Sci. 51: 464-467.

Chemists A.A.O.C. 1995. Approved Methods of AACC, Method 46-12. Am. Assoc. Cereal Chem., St Paul, MN, USA. Chen M.H., Huang L.F., Li H.M., Ho S.L., Chen Y.R. and Yu S.M. 2004. Signal peptide-dependent targeting of a rice alpha-amylase and passenger proteins to plastids and extracellular compartments of plant cells. Plant Physiol. 135: 1367-1377.

Chen M.H., Liu L.F., Chen Y.R., Wu H.K. and Yu S.M. 1994. Expression of alpha-amylases, carbohydrate metabolism, and autophagy in cultured rice cells is coordinately regulated by sugar nutrient. Plant J. 6: 625-636.

Chen P.W., Lu C.A., Yu T.S., Tseng T.H., Wang C.S. and Yu S.M. 2002. Rice alpha-amylase transcriptional enhancers direct multiple mode regulation of promoters in transgenic rice. J. Biol. Chem. 277: 13641-13649.

Chikwamba R.K., Scott M.P., Mejia L.B., Mason H.S. and Wang K. 2003. Localization of a bacterial protein in starch granules of transgenic maize kernels. Proc. Natl. Acad. Sci. USA 100: 11127-11132.

Chiu W., Niwa Y., Zeng W., Hirano T., Kobayashi H. and Sheen J. 1996. Engineered GFP as a vital reporter in plants. Curr. Biol. 6: 325-330.

Dinges J.R., Colleoni C., James M.G. and Myers A.M. 2003. Mutational analysis of the pullulanase-type debranching enzyme of maize indicates multiple functions in starch metabolism. Plant Cell. 15: 666-680.

During K., Hippe S., Kreuzaler F. and Schell J. 1990. Synthesis and self-assembly of a functional monoclonal antibody in transgenic Nicotiana tabacum. Plant Mol. Biol. 15: 281-293.

Hansen L.P., Hosek R., Callan M. and Joens F.T. 1981. The development of high-protein rice flour for early childhood feeding. J. Food Technol. 35: 38-43.

Ho S.L., Tong W.F. and Yu S.M. 2000. Multiple mode regulation of a cysteine proteinase gene expression in rice. Plant Physiol. 122: 57-66.

Hong C.Y., Cheng K.J., Tseng T.H., Wang C.S., Liu L.F. and Yu S.M. 2004. Production of two highly active bacterial phytases with broad $\mathrm{pH}$ optima in germinated transgenic rice seeds. Transgenic Res. 13: 29-39.

Hood E.E., Helmer G.L., Fraley R.T. and Chilton M.D. 1986. The hypervirulence of Agrobacterium tumefaciens A281 is encoded in a region of pTiBo542 outside of T-DNA. J. Bacteriol. 168: 1291-1301.

Itoh K., Yamaguchi J., Huang N., Rodriguez R.L., Akazawa, T. and Shimamoto K. 1995. Developmental and hormonal regulation of rice $\alpha$-amylase (RAmylA)-gus $A$ fusion genes in transgenic rice seeds. Plant Physiol. 107: 25-31.

Jiang H., Dian W. and Wu P. 2003. Effect of high temperature on fine structure of amylopectin in rice endosperm by reducing the activity of the starch branching enzyme. Phytochemistry 63: 53-59.

Juliano B. 1985. Criteria and test for rice grain quality. In: Juliano B.O. (ed.), Rice Chemestry and Technology. American Association of Cereal Chemists, St Paul, pp. 443-513.

Juliano B.O. 1971. A simplified assay for milled rice amylose. Cereal Sci. Today 16: 334-338.

Kubo A., Fujita N., Harada K., Matsuda T., Satoh H. and Nakamura Y. 1999. The starch-debranching enzymes iso- amylase and pullulanase are both involved in amylopectin biosynthesis in rice endosperm. Plant Physiol. 121: 399-409.

Lin F.P. and Leu K.L. 2002. Cloning, expression, and characterization of thermostable region of amylopullulanase gene from Thermoanaerobacter ethanolicus 39E. Appl. Biochem. Biotechnol. 97: 33-44.

Liu Q., Wang Z., Chen X., Cai X., Tang S., Yu H., Zhang J., Hong M. and Gu M. 2003. Stable inheritance of the antisense Waxy gene in transgenic rice with reduced amylose level and improved quality. Transgenic Res. 12: 71-82.

Lu C.A., Lim E.K. and Yu S.M. 1998. Sugar response sequence in the promoter of a rice alpha-amylase gene serves as a transcriptional enhancer. J. Biol. Chem. 273: 10120-10131.

Mathupala S.P., Lowe S.E., Podkovyrov S.M. and Zeikus J.G. 1993. Sequencing of the amylopullulanase (apu) gene of Thermoanaerobacter ethanolicus 39E, and identification of the active site by site-directed mutagenesis. J. Biol. Chem. 268: 16332-16344.

Morita T. and Kiriyama S. 1993. Mass production method for rice protein isolate and nutritional evaluation. J. Food Sci. 58: 1393-1397.

Murata K., Tanaka Y. and Kawaguchi T. 1973. Comparison between nutritional value of rice and wheat protein. Nut. Rep. Int. 7: 93.

Nishi A., Nakamura Y., Tanaka N. and Satoh H. 2001. Biochemical and genetic analysis of the effects of amylose-extender mutation in rice endosperm. Plant Physiol. 127: 459472.

Patindol J. and Wang Y.J. 2003. Fine structures and physicochemical properties of starches from chalky and translucent rice kernels. J. Agric. Food Chem. 51: 2777-2784.

Preiss J. 1991. Biology and molecular biology of starch synthesis and its regulation. In: Miflin B.J. (ed.), Oxford Surveys of Plant Cellular and Molecular Biology, Vol 7. Oxford Universiity Press, Oxford, UK pp.59-114.

Shaw J.F. and Sheu J.R. 1992. Production of high-maltose syrup and high-protein flour from rice by an enzymatic method. Biosci. Biotech. Biochem. 56: 1071-1073.

Sheu J.J., Yu T.S., Tong W.F. and Yu S.M. 1996. Carbohydrate starvation stimulates differential expression of rice alpha-amylase genes that is modulated through complicated transcriptional and posttranscriptional processes. J. Biol. Chem. 271: 26998-27004.

Slattery C.J., Kavakli I.H. and Okita T.W. 2000. Engineering starch for increased quantity and quality. Trends Plant Sci. 5: 291-298.

Terada R., Nakajima M., Isshiki M., Okagaki R.J., Wessler S R. and Shimamoto K. 2000. Antisense waxy genes with highly active promoters effectively suppress waxy gene expression in transgenic rice. Plant Cell Physiol. 41: 881-888.

Tetlow I.J., Davies E.J., Vardy K.A., Bowsher C.G., Burrell M.M. and Emes M.J. 2003. Subcellular localization of ADPglucose pyrophosphorylase in developing wheat endosperm and analysis of the properties of a plastidial isoform. $\mathbf{J}$. Exp. Bot. 54: 715-725.

Thevenot C., Lauriere C., Mayer C., Simond-Cote E. and Daussant J. 1992. alpha-Amylase changes during development and germination of maize kernels. J. Plant Physiol. 140: 61-65.

ToKi S. 1997. Rapid and efficient Agrobacterium-mediated transformation in rice. Plant Mol. Biol. Rep. 15: 16-21. 
Visser R.G.F. and Jacobsen E. 1993. Towards modifying plants for altered starch content and composition. Trends Biotechnol. 11: 63-68.

von Heijne G. 1985. Signal sequences. The limits of variation. J. Mol. Biol. 184: 99-105.

Williams S.1984. Cereal Foods. Chapter 14. in Official Methods of Analysis of the Association of Official Analytical Chemists, 14th ed. pp. 251-252.

Wu C.Y., Adachi T., Hatano T., Washida H., Suzuki A. and Takaiwa F. 1998. Promoters of rice seed storage proteins genes direct endosperm-specific gene expression in transgenic rice. Plant Cell Physiol. 39: 885-889.
Xie Y. and Wu R. 1989. Rice alcohol dehydrogenase genes: anaerobic induction, organ specific expression and characterization of cDNA clones. Plant Mol. Biol. 13: 53-68.

Yu S.M., Lee Y.C., Fang S.C., Chan M.T., Hwa S.F. and Liu L.F. 1996. Sugars act as signal molecules and osmotica to regulate the expression of alpha-amylase genes and metabolic activities in germinating cereal grains. Plant Mol. Biol. 30: 1277-1289.

Zeeman S.C., Northrop F., Smith A.M. and Rees T. 1998. A starch-accumulating mutant of Arabidopsis thaliana deficient in a chloroplastic starch-hydrolysing enzyme. Plant J. 15: 357-365. 